Tattva, Vol. 3, No. 7, January - June 2017, pp. 81-90

ISSN 0975-332X | https://doi.org/10.12726/tip.5.6

\title{
Tattua
}

JOURNAL OF PHILOSOPHY

\section{MYSTICS ARE BEYOND RELIGIONS}

\section{Swami Paramananda}

Mysticism is an experience and without experience, religion, spirituality and even mysticism itself become mere philosophy; and philosophy is a mental affair. All bounds, discussions and discrimination are created by the mind. Mysticism beyond bounds means to go beyond the mind. That is linked to the science of spirituality or the science of meditation; therefore the whole question is about practice, not talk or debate. We have to ask ourselves the following question: Are we practising something that will break the barrier created by the mind, or are we trying to involve the mind, which is itself the barrier?

Mysticism alone is without bounds. Mysticism is the experience of the mystic and a mystic is an individual whose being has flourished and merged into the truth that I call 'The Mystery'. God or Truth remains a mystery even after the great experience of enlightenment, Buddhahood or Nirvana. "The most beautiful thing that one can experience is the mysterious. It is the source of all true art and science," said Albert Einstein. Butl say it is the source of this wonderful universe and countless other universes! That which is beyond human mind is indeed mysterious and if God is not mysterious, then what is it? Those who have known will definitely say that It is mysterious or a mystery.

God has always been and will always remain a mystery because even after the ultimate experience, It is not fully known and cannot be expressed in words. It is beyond the mind that one experiences oneness and unity and from that spring love and all the known virtues which flow spontaneously. The mystic is one who has merged into and become one with that mystery. He has transcended or gone beyond 
the mind after years of intense meditation, which is the ant and science that leads to a profound understanding of the nature of the mind. Mystics are not necessarily knowledgeable people. Jesus, Kabir, Ramakrishna and many others were illiterate and did not even know the scriptures. Experiencing God does not imply knowing everything. On the contrary, it implies losing all knowledge and what remains is self-knowledge. One sees nothing but oneself and even that remains a mystery by its very nature.

When I say God is a mystery, it does not imply that God cannot be known at all. I simply mean that though it can be known, felt and tasted, yet It remains a mystery. This may seem contradictory, but that is the nature of truth. The art and science that can make such a union possible is called mysticism, pure religion or spirituality. To realise God, our human nature has to die through the practice of meditation. That is what Jesus meant, when he said that man should be born again in order to have eternal life. The Hindus call it to become a dwii, a twice-born.

Enlightenment or cosmic consciousness is attained by using certain means, which after an advanced stage are of no use. These means later evolve into religions. The paths may be different but the destination is one-merging with the Whole. Some rare mystics are at ease with a multitude of paths and methods and can guide seekers on specific paths according to each one's temperament and inclination. All the methods, words, parables, stories, koans and scriptures used by prophets and enlightened beings are only means to help the seeker to attain a no-mind state or to develop an interest towards that state. The words are not the truth but simply pointing fingers. Alas! In their ignorance, people have caught the finger, moulded it in their own way and according to their own likeness and have given it the name of religion or God..Different masters use different devices according to the evolution of the people, time, circumstances and environment where they incarnate.

Pure religion or spirituality cannot be taught by lay people or even highly intellectual ones. It brings messages from beyond the mind, senses and body, beyond matter and beyond perceptive reality. Expert guidance is needed. It is like the study of highly advanced physics and mathematics, which requires guidance of accomplished physicists and mathematicians. Many people have done and are still doing much harm by explaining religions though they have no spiritual experience. They lead people, exploit them and are themselves misguided by their ego. Such people even have degrees in religious scriptures: MA's, PhD's and what not! They are, however, like the person who knows the abc of making sugar, but has never seen or tasted it. Kabir, a famous Indian mystic, Sai Baba of Shirdi, Ramakrishna, Jesus and Mohammed were all academically illiterate, yet that did not prevent them from being the stars of the earth. 


\section{The Mystery}

The Bible says that no man has ever seen the face of God. Then why so much talk of that which has never been seen? Scriptures cannot be taken literally; we should know how to read in between the lines. The truth is that to know or to experience lt, the mind must dissolve and when this happens, who will know, who will describe, who will be the witness? Fortunately, many who have merged with the Infinite have retained, by the will of that mystery, a little humanness and it is that which helps to give a faint idea of the unknown to others. They are the mystics.

The mysterious is such because even after experiencing It, one feels that one does not really know it and one becomes aware of one's 'nothingness'. Thus Socrates said, "The only thing I know is that I know nothing." Indeed, in front of that mystery, one realises how much one is nothing, ignorant and tiny. The mind thinks it knows a lot. But when it dissolves in That, all its knowledge vanishes like a dewdrop in the morning sun. That is what I call Vedanta - the end of knowledge.

God has infinite faces. The Upanishads talk about Sat-Cit-Ananda and Atma. Sat means existence, cit is consciousness and ananda is bliss. The Upanishads and the Vedas lay emphasis on the absolute nature of God. It is formless, eternal, infinite and untouched by the whole existence of names and forms. The universe is like a mirage, a dream in His mind. Ancient Indian mystics or rishis refer to God as Atma or the Self as He is uncreated, eternal and wisdom infinite. They do not see creation as being separate from God; for them creation is nothing but God, just like waves are a modification of the ocean.

Creation, preservation and dissolution are characteristics of 'Brahm' or the Supreme Mind, who is a witness to the universal drama. Creation is not an act of desire, but a spontaneous overflow of ideas. And since God is perfect, whatever comes out of $\mathrm{Him}$ is perfect. However, the idea of being perfect as understood in the Christian religion and in the mind of people is different from what it is in reality. For instance, a layperson will say, "If God is perfect, then why is there so much imperfection in His creation?" From his point of view, the question seems logical, but how does God see things? And how can you give the right answer when your perception is fragmented and blurred? This is why enlightened beings will say that God is a mystery and they say so not because they do not know or are evading the question. The truth is that until and unless your mind is not completely freed from impressions, you cannot have direct perception. 


\section{The Ultimate Stuff of the Universe as experienced by Mystics}

For the mystic, the world is nothing but the waves, ripples and bubbles of an infinite ocean of energy. Existence is energy and energy is conscious and boundless. Matter is, in the words of Professor David Bohm, but a drop in an infinite ocean of energy. The mere presence of that conscious force brings about the birth of the universe. This implies that God does not create but simply witnesses the birth, evolution and dissolution of the universe. From this angle, It does not interfere with the good march of the cosmos.

That which appears to be void or filled with air for the layman is, in fact, filled with an extremely subtle stuff which is the real space. It is known that space contains atoms, molecules, particles, waves and finally light, which is the subtlest. The latest discovery is that even space and creation are only an aspect of an infinite ocean of energy. With the penetrating eyes of meditation, the mystic goes to that ultimate stuff and beholds it as a blue 'substance' which is beyond light as is known by science. The blue substance beheld by the mystic is an infinite ocean of power. My guru, Swami Veervasantha says that this is the subtle Blue Matter or Space Blue and the purest form of energy. When Professor David Bohm said that matter is only a drop from an infinite ocean of energy, he was unknowingly referring to that pure homogeneous substance, which is the ultimate building block of the Universe.

Professor Bohm has also spoken about the implicate order and explicate order. The implicate order has infinite depth. He has proposed that in its inward recesses, both matter and consciousness have their source and get unified. The subtle Blve Matter or Space Blue to which Swami Veervasantha referred is mind, and mind is both matter and consciousness. It is both energy and the void, it is Satti-Shiva, Prakriti-Purush. Therefore, the infinite Space Blue or the Mind of God can be compared to the implicate order of Professor Bohm. At times, some scientists have glimpses of the Beyond, but given that they depend solely on logic, mathematics and theory and do not practise meditation, they evade the glimpses and thus the very truth is missed.

Mystics go further than science to say that the essence of the universe is not only energy of infinite density and vibration but the highest truth is that it is also pure consciousness, as if a living void completely free of all motion, wave, form and colour. Buddha named the same thing Nirvana, but since he did not explain it in scientific terms, he was taxed with being an atheist. How do we know that the universe is pure consciousness, sheer bliss and ineffable peace? This is indeed a 
very challenging question! The answer is the mind, which is also energy congealed. And since the mind does not die but simply undergoes transformation, the mind can be transformed to merge with the essence of the universe to experience the above-mentioned qualities. William Blake, the famous mystic-poet, has made a very beautiful statement: "Energy is delight." I am sure he must have tasted the truth of his declaration at least to a little extent. Yes, indeed! The more we are filled with energy, the more delightful we feel. Therefore if we can make our mind merge with the essence of the universe, then we will no doubt experience delight, peace, consciousness and from these, many other virtues will spring.

\section{The Freedom of Enlightenment}

Only a mystic or an enlightened person is free and here I am referring to mental freedom, which is the real and ultimate freedom. It is freedom from unconsciousness, from the notion of 'I am separate from the Whole', from ceaseless thinking, greed, lust, hatred, from the duality of evil-good, morality-immorality. It is freedom from the weight of body consciousness and bookish knowledge, from the notion of ' 1 you, mine-thine', from action and inaction, from humility and arrogance, from belief and disbelief and other dualities. Such a state, however, is inconceivable to a lay mind. This is why when an enlightened being behaves at times like an ordinary mortal, lay people think, "But he is like us!" People usually think an enlightened being should behave in a particular manner, be strictly vegetarian, be a celibate and abstain from any form of enjoyment. This is totally absurd.

Enlightenment is a state of being, a state of absolute freedom. The person is not; instead it is the fire of pure consciousness which is constantly manifesting. For such a soul to stay in his body, he has to retain some human features which are like the ash of a burnt wick. For him, the world is nothing but the waves, ripples and bubbles of an infinite ocean of energy.

It is strange that many people of meagre intelligence believe that such great souls should be disciplined, follow norms and live according to a certain pattern while they themselves do not do these things. God knows from where people get such stupid ideas! Who is freer to enjoy, the student or the teacher? The teacher is free as he has no exam behind the door. He can therefore enjoy, but the student still has to work hard and make sacrifices. An enlightened being is free; he now lives as part and parcel of the whole, not as a separate unit. His every move is that of the whole. The state of enlightenment is transcendental.

Any person who attains enlightenment is identified to that state, some fully, others not so fully. The reason that some are not totally identified is that they have to come 
down to a lower level of consciousness to help others. However, their state of consciousness is nevertheless very high in comparison to aspirants and meditators. Also, they identify themselves with a state of being, not with the ego or the body. Such beings always live in the 'Aham Brahmasmi' state, meaning 'I am Brahmanthe Absolute.' It is impossible for non-meditators to comprehend that. This is why enlightened beings have few disciples when they are alive, but many followers after their demise. Every individual is essentially as free as space and even more, we are all chit or space consciousness, free, pure and unblemished. Enlightened beings are not 'good' in the sense worldly people understand it, nor are they moralistic. They are virtuous but their virtuosity is a natural spontaneous overflow of their being. Dharma or righteous living is not a straight line that should be followed. Many a time, it is based on circumstances and is therefore fluid. So are the enlightened ones, thus they can easily adapt to circumstances. For example, they can be meateaters; Moses, Jesus and Mohammed are but a few examples. Krishna, Rama, Mohammed had to take up arms, but that did not make them violent people.

It may be very difficult to understand that they were the most non-violent people who ever lived. Their non-violence was a state of their being; it was not mechanical, moralistic or based on any bookish principle. They were simply practical individuals. Having waged a war, they do not feel guilty or regret because they know that it is the body that dies, not the soul. Besides, a person may have a human body but a devilish mind and such individuals who are threats to human society should be eliminated. In fact, enlightened beings such as Krishna, Rama and Mohammed act only in self-defence.

Rama killed Bali from behind when the latter was engaged in a dual with his brother Sugriv. Mohammed had taken the sword, which is a sign of violence, blood and killing in the mind of people. Krishna and the Pandavas, who were the very symbol of dharma, had won the war by breaking many rules. Most of those who criticise or do not understand such behaviours of the great ones are themselves not spiritual and non-virtuous, but rather moralistic and mechanically virtuous.

Laypeople are caught in the duality of good and evil without being practical, thus they suffer when they are faced with certain circumstances. 'Good' and 'bad' reflect the materialistic and dual attitude of the mind while enlightenment or Godrealisation is holistic, non-dual and transcendental. Only people who have transcended duality can be really practical in situations that seem most conflicting and confused. They can play with the laws. The cosmos is a play and the liberated ones know this.

For them, commandments, religions and the whole world are mere illusions; there are no dos and don'ts. They have no aim as they have reached home. However, 
society or the mob cannot understand that. This is why they have always condemned them. When Jesus healed during the Sabbath, he was said to have broken the laws and he was criticised for that. When Krishna stole the clothes of young damsels who were bathing in the river and asked them to come out, he seemed to be immoral in the eyes of some people. But Krishna is free from morality and immorality because he is free from lust.

When do we need norms, laws, rules and regulations? When people are unintelligent, unpractical, dishonest, complexed and selfish. What's the use of the laws if one is free from them? Being alone and free from the laws of matter, morality and immorality, good and evil and all other dualities, they do not make wrong use of their freedom, they only use it to help other individuals. Krishna, for example, did not make the Pandavas break the rules of the war for his own sake, but rather for the welfare of society. Jesus did not heal during the Sabbath for vested interest; he was motivated by mere compassion.

A mystic understands that not everyone is enlightened; therefore at times he will have to behave like an ordinary person in order to fit in society. Otherwise, he will not be able to help others. But that is not always possible. Few people will understand the esoteric dimension behind certain instances such as when Jesus cursed a fig tree. The mystic usually becomes a misfit in society. Most people are unconscious or with very little consciousness. When Jesus proclaimed himself as the Son of God, his people said, "Is this not the son of Joseph and Mary? Is he not the one who was helping his father in his workshop? How come that now he is proclaiming himself as the Son of God?" Similarly, when Al-Hillaj Mansoor uttered, "Analhaq," he was chopped to pieces.

Many mystics have run into trouble because they could not conceal their realisation. It is indeed very difficult to conceal such a vast and blissful happening. The behaviour of different mystics varies. Songs, dance, poems and strange statements about love, God and so on emanate from those who express through the heart, whereas those who express through the head will write, talk and make unusual statements. Those who are enlightened are no more. They have to be understood: it is the divine energy manifesting through them with a very little human consciousness. But how can those who are nearly asleep and a prey to greed, anger, lust, hatred and others understand those who live in the realm of light and consciousness?

God enioys the world through the mystics. That is why they say, "Not I, my Lord, but thou." Krishna said, "I am the Supreme Enioyer." What a wonderful.truth! Yes, if there is only One, how can there be many doers? The greatest illusion of the mind is that it thinks of itself as a body, hence the doer. The mystic or the devotee will say, "God is doing actions through me." The joy of such a realisation is inexpressible. 


\section{The Transformation and Silencing of the Mind}

Man, as he is now, is only a potential. It is only when he has realised and lived fully his oneness with the Absolute that he is fulfilled. Why should anyone seek to live in oneness with existence or God? That seems to be very far-fetched to most people, even for the so-called religious people. The question is not of goal or aim, philosophy or morality, but that of perception. It is like a man who is blind and believes that there is darkness everywhere, which he finds very natural. He even believes that everyone is like him. Similarly, existence is one, homogenous and boundless, but man's perception is limited to his body and mind.

Though the ultimate possibility of human life is to realise his oneness with God, there are many relative possibilities or opportunities in life. Human life was not meant only to attain union with the Absolute. If such were the case, then life would have been completely different. That vast illusion came into being to be enjoyed both materially and spiritually. Materially, it can be enjoyed through the senses when one is still in duality and ignorance. However, such enjoyment has its own risk. The other way of enjoying the world is spiritually and this means that now I am aware, I see the world as a play, a dream or an illusion. Before enlightenment, I used to do everything like a sleepwalker, now I do the same fully conscious.

The process of transforming the mind that can lead to the ultimate realisation is what I call spirituality. In this process we need no Bible, Gita, Quran or other scriptures. Who can deny that our body is a replica of the universe in miniature? If our body can dissolve into it, then why not the mind? This simple understanding and logic can make us deeply religious. If our body is a tiny universe, then its essence is the essence of the universe. Then what does one have to do apart from simply relaxing and merging one's mind into the universal mind?

When the body dies, the mind does not die because it is too subtle. Its death can come only through certain methods. In fact, its death brings a new regeneration, a new life, an oceanic feeling or oneness with the whole existence. What I find more wonderful is that this experience is the right of one and all in this very body. Once this experience is acquired, the whole of humanity can become paradise-like. Ancient mystics knew this, but they had no scientific explanation. When Jesus talked of 'one earth, one humanity', he was not dreaming. I have myself gone through the experience. In fact, anyone else can go through it, provided that one is willing to learn and ready to undergo the great transformation.

Silence of the mind is the key. That is why, in the Bible, God says, "Be still and know that I am." Normally, the mind is constantly active with thoughts, ideas, dreams, 
desires, ambitions, negative and positive moods and above all an incredibly thick layer of unconsciousness. Silence is the complete cessation of all mental activities leading to the total dissipation of the unconscious layers. Consequently, there is a state of pure consciousness, a peace that is boundless, ineffable, transcendental and bubbling with infinite potentialities.

The state of pure consciousness is everything. It is the energy that becomes the whole existence. We function by its virtue. When Jesus said, "You have eyes but you do not see; you have ears but you do not hear," he was referring to the blockage of the subtle senses of hearing and seeing. In other words, our perception is greatly reduced due to our blurred mind. This means that we listen, see and perform every activity with the mind; the body and the senses are only the medium. Therefore, if the mind is loaded with thoughts, impressions, emotions, concepts and ideas, how can it see, listen, think, reason and hear correctly?

The whole of the mystical or spiritual science is based on silencing the mind. If means bringing the mind to its original state of Pure Consciousness. I would say that silence is the dawn of intelligence. Krishnamurti exhorts people to be attentive and calm; these are aspects of the state of a pure mind. Attentiveness is of paramount importance if we wish to learn. The silence of the mind is like the sharp penetrating rays of the most sophisticated apparatus by which scientists probe the womb of matter and the world of sub-atomic particles. From silence is bom the whole existence. In silence it exists and to silence it will go back. Deep within matter is silence. The harmony of existence is due to an ineffable silence.

\section{Mysticism is beyond knowledge}

Mysticism can be compared to the particle-wave duality. The particle is relative reality while the wave is the ultimate reality. Similarly, the individuality of an unenlightened person is a relative reality, while the mystic's experience of being pure consciousness is the ultimate reality. The perception of life through the relative reality of individuality is an illusion as the person is covered with a thick layer of unconsciousness, which itself is formed by an amalgamation of habits, beliefs, impression and many other conditionings. Therefore, first the individual has to be liberated from them, then he can flower and merge into the Mystery. The process and the experience are what I call mysticism. It has nothing to do with any belief or religion.

The scholar or the pundit has much knowledge, while the mystic knows but his self. So far as knowledge is concerned, one will always have to learn if one so wishes, but that concerns the person who has not reached his destination. The fact is that 
the enlightened one has reached his destination. If he decides to stay in the world, it is for the purpose of guiding others to grow spiritually. If you can conceive and think about something, then it is no longer boundless; it is limited. So-called religious people think that God can be known as it has been revealed and defined in the scriptures - this implies that $\mathrm{He}$ is within bounds. For those 'people of the book', everything is contained in the scriptures. This form of limitation is called maya - the great illusion. There are also people who use the pretext of being always a seeker or a learner just to avoid facing themselves or a spiritual guide, who is an egocracker. They think they are humble when in reality it is the ego clad in humility.

The mystic has stopped learning because he has reached the ultimate goal. Learning involves action and effort, while enlightenment is rest, silence, awareness, pure knowing, bliss, love and freedom. Life is like a university; the yogi has learnt his lessons and thus is free. There is nothing else left to be learnt for one who has known his self. What would one who has merged with That, from which all material as well as spiritual knowledge flows, learn from the scriptures or any person?

This is what the Upanishads imply when they say, "Know that by knowing which all else gets known." What could that be if not the self! The Upanishads form part of the last part of the Vedas and are thus referred to as Vedanta. However, there is a secret behind it and who else apart from an enlightened being can speak out the truth that the word Vedanta conceals? My realisation is that the word Vedanta means 'the end of all knowledge' or 'beyond knowledge', from the root words vid meaning knowledge and anta meaning end.

Knowledge is only a ladder with the help of which one may ascend to the realm of the Absolute. Once the Absolute is attained, then all knowledge becomes useless, at least for the enlightened one. The world is full of knowledgeable people, but very poor in experienced people so far as spirituality is concerned. What avails a man if he has abundant knowledge yet is self-ignorant! If the world is extremely sick today, it is just because people have drifted from self-knowledge to secular knowledge. We have even reduced self-knowledge to bookish knowledge-such is the cunningness of the mind.

When all knowledge ends, when the mind is completely silent but fully awake, then experience dawns. This is self-realisation. Only the realisation of knowledge can bestow on you the highest good - all else is secondary. And only the guidance of a mystic can lead to self-realisation or enlightenment. He alone can reveal the esoteric truth behind scriptures and then share the effulgence of the Beyond with humankind. 